\title{
819
}

\section{プール液中蒸気放出凝縮過程における凝縮振動に及ぼす蒸気過熱度の影響 \\ Effect of Superheat on Oscillatory Condensation of Vapor Directly Discharged into Subcooled Liquid Pool}

\section{$\bigcirc$ 新見征之(九大院)}

Masayuki NIIMI, Dept. of Mech. Eng. Science, Graduate School, Kyushu Univ.

正 森 英夫(九大)

Hideo MORI, Dept. of Mech. Eng., Kyushu Univ.
正 濱本芳德(九大)

Yoshinori HAMAMOTO, Dept. of Mech. Eng., Kyushu Univ.

Key Words: Experiment, Condensation, LOCA, Pressure Oscillation, Subcooled Liquid, Superheat, Vapor discharge

\section{1. まえがき}

沸騰水型原子炉では，冷却材培失事故における格納容器内 部の圧力抑制時や逃し弁作動時に放出される高温の蒸気を, ベンド管を通じて圧力抑制プール内で凝縮させる.蒸気がプ ール液中で㠜縮する際には, 圧力振動が音響を伴って発生し, 格納容器を損傷させる危険性がある.

蒸気のプール液中放出凝縮過程における圧力振動に関す る従来の研究(1),(2)では, 試験流体に水あるいはフレオンを用 い, 大気圧の乾き飽和蒸気をサブクール液中に放出する試験 が行われ，サブクール度が大きくなると, 圧力振幅は増大し 極大を経て減衰すること, また流量や放出管径が影響を及ぼ すことなどが明らかにされている。

一方, 実機では過熱蒸気が放出されることが想定されるに もかかわらず，実験の難しさからか，そのような研究はまた ない。そこで，著者らは，先に(3),(4)，試験流体に $\mathrm{HCFC123}$ を用いた試験を行い, 放出蒸気の過熱度, またプール圧力の 圧力振幅に及ほすす影響を検討した. HCFC123 は水に比べて 潜熱が小さく, 高温高圧蒸気放出凝縮の詳細な試験が可能で ある.管内径 $10 \mathrm{~mm}$ と $20 \mathrm{~mm}$ の放出条件で試験を行った結果, 振幅が極大に到達するまでの低サブクール度域において, 蒸 気過熱度は圧力振幅にほとんど影響を及ぼさないことがわ かった(3),(4)

本報では，新たに管径 $5 \mathrm{~mm}$ の放出管で試験を行い，振幅 が極大となる高サブクール域について，蒸気過熱度の影響を， 明らかにしたので，その結果を以下に報告する。

\section{2. 試験装置および試験方法}

試験は，先に製作した試験装置 ${ }^{(3),(4)} に$ 内径 $5 \mathrm{~mm}$ の放出管 を取り付けて行った。装置は, 気化器, 流量計, 流量調整弁, 凝縮器のほか，これらをつなぐ配管により構成される。

図 1 に凝縮器を示す. 上端部中央から垂直下向きに放出管 が取り付けてあり, 放出蒸気の凝縮に伴う圧力変動と温度変 動の測定のために, 凝縮器内に複数の圧力トランデューサと 熱電対が設置されている. 圧力は压力トランスデューサで, 温度は E 型シース熱電対で測定する. 放出管は SUS316 製の 外径 $8 \mathrm{~mm}$, 内径 $5 \mathrm{~mm}$, 全長 $822 \mathrm{~mm}$ の管である. 放出管取り 付け部上端から上流 $270 \mathrm{~mm}$ の位置で流入蒸気の温度を, ま た $370 \mathrm{~mm}$ の位置で圧力をそれぞれ測定している，凝縮器内 では，上部 1 箇所で気相部の圧力を，プール液中では，放出 管先端と同一水平面上高さで半径方向に $300 \mathrm{~m}$ の壁面上 3 箇 所と底部 1 箇所で液相の圧力を，それぞれ測定している。温 度は, 凝縮器上部 1 䇢所で気相の温度, 液中 7 箇所で液相の 温度を測定している。

試験流体には HCFC123を用い，物性值はNISTの REFPROP $^{(5)}$ より求めた.

試験方法も先の試験と同様で, 気化器内で所定の温度の蒸

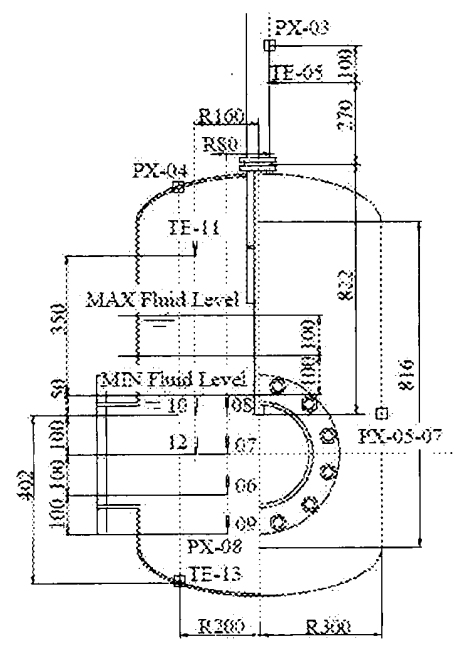

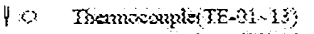

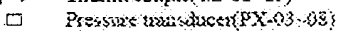

Fig. 1 Condensation tank

気を発生させ, 流量調整弁で質量速度 $3400 \mathrm{~kg} /\left(\mathrm{m}^{2} \cdot \mathrm{s}\right)$ に調整し，

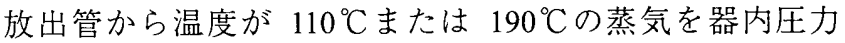
$120 \mathrm{kPa}$ の凝縮器の過冷プール液中に放出凝縮させる. その際 に発生する圧力振動の振幅, プール液温の測定および凝縮様 相の光学的観察（撮影速度 $10000 \mathrm{fps}$ で 1 秒間撮影）を行う. 蒸気流量, 温度および圧力の測定はサンプル周期 $20 \mathrm{kHz}$ で 3 秒間測定した。1 秒間毎（20000 点）のデータを整理し，流 量の安定している間のデータを測定値とした.

プール液のサブクール度は, 凝縮器の気相圧力に対応する 飽和温度と放出管先端に最も近い TE- 08 で測定された液温 との差で求めた。また, 放出蒸気の過熱度は, 流入蒸気温度 と気相圧力に相当する飽和温度との差とした。

液相部における圧力振動の圧力振幅としては, 放出管先端 と同一水平面上 3 箇所の測定値の平均值を用いた（3 箇所の 值の間に差はほとんどない)。圧力振幅の評価には，二乗平 均平方根值 ( $\mathrm{rms}$ 值) と十点平均高さ值 (Rz10 值)を用いた. なお，プール液中で圧力振動が発生していても，気相部の压 力はほぼ一定に保たれていた。

\section{3. 試験結果}

凝縮様相と圧力振動の一例として, 蒸気温度 $110^{\circ} \mathrm{C}$ （過熱 度 $77^{\circ} \mathrm{C}$ ), サブクール度 $17.5 \mathrm{~K}$ における凝縮様相と圧力振動 の結果を図 2 と図 3 にそれぞれ示す。凝縮様相の観察では, 放出された蒸気塊が下方に伸びていき，下部においてくびれ が発生し, 先端部分が離脱・消滅 (凝縮) しているのがわか る。このときの圧力振幅は $\mathrm{rms}$ 值 $2 \mathrm{kPa}$ 程度で, 周期は $3 \mathrm{~ms}$ 程度である。 
図 4 に，異なる蒸気温度 $110^{\circ} \mathrm{C}$ と $190^{\circ} \mathrm{C}$ (それぞれ過熱度 $77^{\circ} \mathrm{C}$ と $157^{\circ} \mathrm{C}$ ) で得られた圧力振幅（rms 值）を, サブクー ル度に対してプロットし, 比較している.いずれの蒸気温度 でも, 圧力振幅は, サブクール度が大きくなると増大し, 極 大を経て，急激に減衰する傾向を示す．振幅が極大に至るま での低サブクール度域では, 先の結果 ${ }^{(3),(4)}$ と同様, 蒸気過熱 度の違いによる差異はみられない.しかしながら, 極大およ び極大以降の高サブクール度域では, 差がみられ, 蒸気過熱 度の大きい方が，圧力振幅は $\mathrm{rms}$ 值で約 1.3 倍大きく，また 振幅の極大が生じるサブクール度が $3 \mathrm{~K}$ 程度高くなっている のがわかる. なお, 圧力振幅の Rz10 值は, rms 值と比べて, これはサブクール度また蒸気温度によらず，2 倍程度と大き い. 先の $10 \mathrm{~mm}$ と $20 \mathrm{~mm}$ 管の場合 ${ }^{(4)}$ とほほ同じ比率であった。 (文献(4)では 4 倍としているが正しくは 2 倍である)

また，各蒸気温度でのサブクール度 $19 \mathrm{~K}$ と $34 \mathrm{~K}$ (極大前後 のサブクール度)における蒸気塊の収縮, 膨張の様子を図 5 に示す．蒸気温度が高い方が蒸気塊は大きくなっており，蒸 気温度によらず, 圧力振幅が極大に到達する前のサブクール 度 $19 \mathrm{~K}$ では蒸気塊がかなり下方にまで伸びているのに対し， 極大以降の $34 \mathrm{~K}$ では蒸気塊は短くなっている。このとき, 収 縮時に対する膨張時の体積比率はサブクール度 $19 \mathrm{~K}$ では約 2.0 倍, $34 \mathrm{~K}$ ではほほ 1.5 倍であり，この違いが振幅に影響を 及ほしていると予想される。

\section{4. 考察}

蒸気温度が $110^{\circ} \mathrm{C}$ と $190^{\circ} \mathrm{C}$ での凝縮器内圧力 $120 \mathrm{kPa}$ (飽和温 度 $32^{\circ} \mathrm{C}$, 蒸発潜熱 $168 \mathrm{~kJ} / \mathrm{kg}$ )における比エンタルピーはそれ ぞれ $459 \mathrm{~kJ} / \mathrm{kg}$ と $523 \mathrm{~kJ} / \mathrm{kg}$,である. 乾き飽和蒸気からの過熱 度分の比エンタルピー差はそれぞれ $58 \mathrm{~kJ} / \mathrm{kg}$ と $122 \mathrm{~kJ} / \mathrm{kg}$ で, また, 飽和液からの比エンタルピー差はそれぞれ $226 \mathrm{~kJ} / \mathrm{kg}$ と $290 \mathrm{~kJ} / \mathrm{kg}$ であり, 1.3 倍程度の差がある。流入した蒸気の エネルギーの一部は仕事に変換されることになるため, 蒸気 過熱度の違いによって, 圧力振幅の大きさに差が生じること が推測される.高サブクール度域で圧力振幅に差が生じてい るのはその影響が現れているものと予想される。一方，低サ ブクール度域では圧力振幅に差異が見られていない.したが って, 極大をはさむ低サブクール度域と高サブクール度域で 蒸気のエネルギーの仕事への変換メカニズムが異なってい るのではないかと考えられる。

\section{5. あとがき}

蒸気をプール液中で放出凝縮させる際に発生する圧力振 動に関し，異なる蒸気過熱度条件の試験を行い，圧力振幅が 極大に至るまでの低サブクール度域では蒸気過熱度の影響 はないが, 極大や極大以降の高サブクール域では影響が見ら れ, 蒸気過熱度が高いと, 圧力振幅が大きく, また極大が発 生するサブクール度は高くなることを明らかにした。

実機において過熱蒸気が放出されるため, 注意する必要が ある。

\section{参考文献}

(1) 宇多村元昭, 東京大学学位論文 (1985)

(2) 斉藤静夫, 福田真一, 斉藤孝基, 内田秀雄, 日本冷凍協会 学術講演会講演論文集, 冷媒蒸気(R-113)の液中凝縮 (1977)

(3) H. Mori, Y. Hamamoto, M.Ohno, Prof of ICAPP'09, Experimental Study for Research and Development of a Super Fast Reactor(2) Oscillatory Condensation of High Temperature Vapor Directly Discharged into Sub-cooled Liquid Pool, paper 9369(2009)

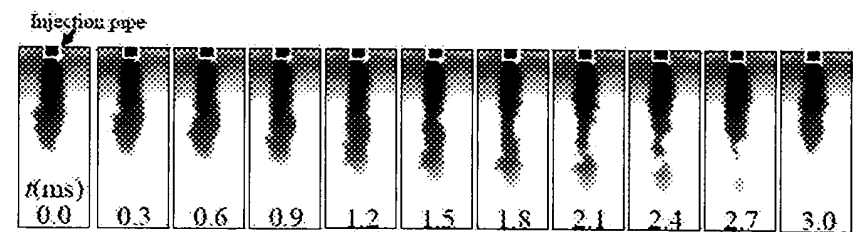

Fig.2 Photos of condensing vapor

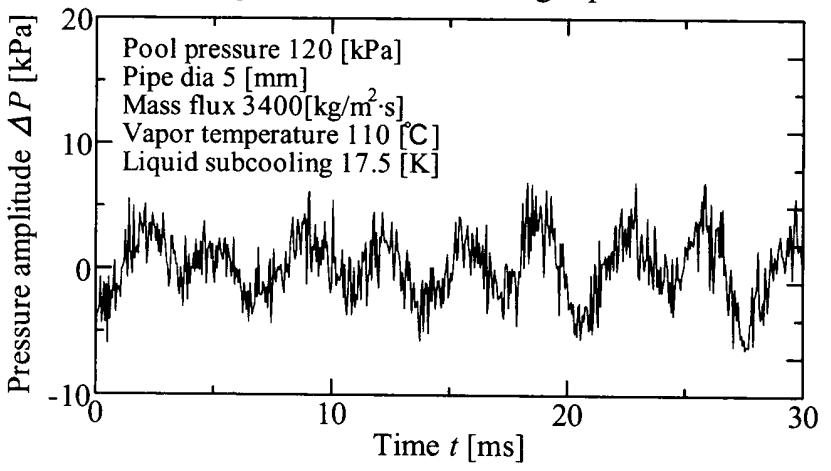

Fig.3 Pressure oscillation

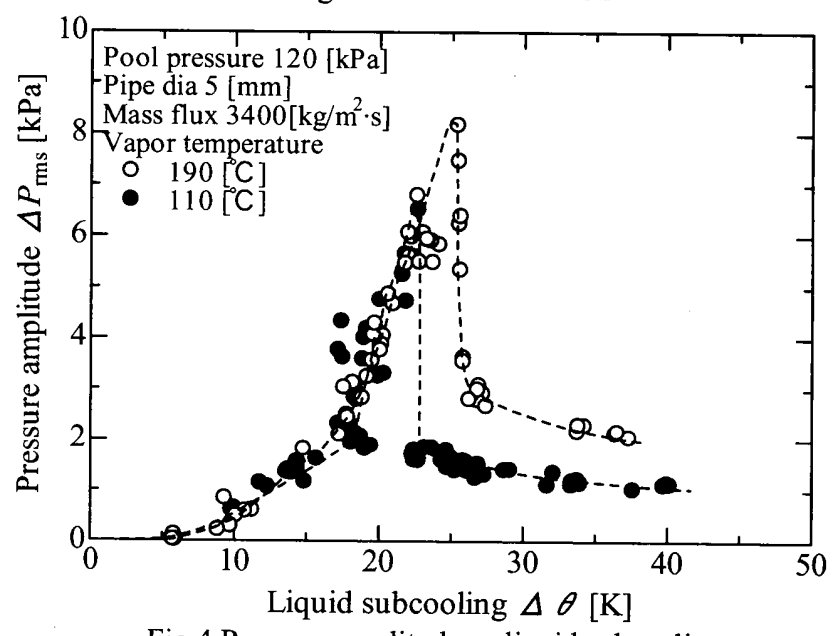

Fig.4 Pressure amplitude vs liquid subcooling

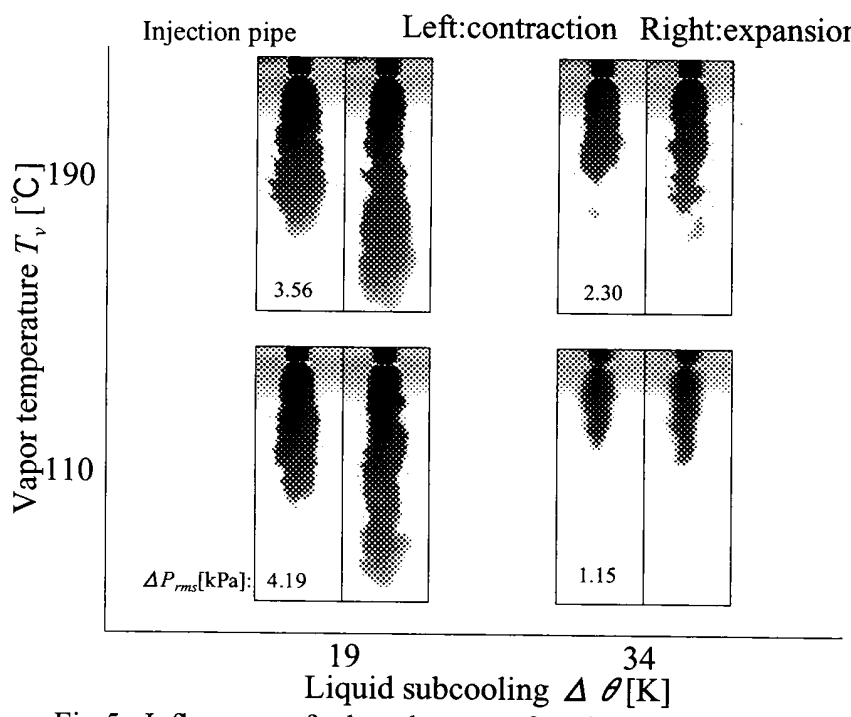

Fig.5 Influence of the degree of subcolling and vapor temperature on the condensing vapor interface shape

(4)文部科学省, 「軽水冷却スーパー高速炉に関する研究開 発」成果報告書(2009)

(5) E. W. Lemon, M. L. Huber, M. O. McLinden : NIST Standard Reference Datebase 23, Version 8.0 (2007) 